\title{
Cloning and sequence analysis of a plasmid-encoded chloramphenicol acetyltransferase gene from Staphylococcus intermedius
}

\author{
Stefan Schwarz*, Uwe Spies $†$ and Marisa Cardoso \\ Institut für Bakteriologie und Immunologie der Justus-Liebig-Universität Giessen, Giessen, FRG
}

(Received 5 September 1990; revised 27 November 1990; accepted 11 December 1990)

\begin{abstract}
The chloramphenicol acetyltransferase gene (cat) of a $3.9 \mathrm{~kb}$ chloramphenicol resistance $\left(\mathrm{Cm}^{\mathrm{R}}\right)$ plasmid from Staphylococcus intermedius, designated pSCS1, was cloned into an Escherichia coli plasmid vector. Sequence analysis revealed a high degree of base similarity with the cat gene of the $S$. aureus $\mathrm{Cm}^{\mathrm{R}}$ plasmid $\mathrm{pC221}$ but there were several differences in the regulatory region. A lesser degree of similarity was observed between the cat gene of the $S$. intermedius plasmid and the cat gene of the $S$. aureus plasmid pC194.
\end{abstract}

\section{Introduction}

Chloramphenicol $(\mathrm{Cm})$ was introduced into clinical use as a broad spectrum antibiotic in the 1950s. Because of its toxicity in bone marrow (Yunis, 1973), its use in man was limited to the control of life-threatening infections (Shaw, 1984). However, in veterinary practice $\mathrm{Cm}$ is used to control many animal infections. Bacterial resistance to $\mathrm{Cm}$ was detected soon after its introduction into clinical use, as seen with other antibiotics. In staphylococci, the determinants for chloramphenicol resistance $\left(\mathrm{Cm}^{\mathrm{R}}\right)$ occur exclusively on small plasmids (Lyon \& Skurray, 1987). The $\mathrm{Cm}^{\mathrm{R}}$ plasmids from human Staphylococcus aureus strains have been studied intensively, and three distinct plasmid families have been differentiated (Gillespie \& Skurray, 1988).

However, little is known about $\mathrm{Cm}^{\mathrm{R}}$ in staphylococcal species pathogenic to animals. Recently, $\mathrm{Cm}^{\mathrm{R}}$ plasmids have been isolated from 'equine' S. sciuri (Schwarz et al., 1990 a), 'canine' S. epidermidis (Schwarz et al., 1990b), 'porcine' S. hyicus (Schwarz et al., 1989a) and 'canine' S. intermedius strains (Schwarz et al., 1989b). All staphylococcal $\mathrm{Cm}^{\mathrm{R}}$ plasmids encode a common resistance mechanism, namely an inducible $\mathrm{Cm}$ acetyltransferase (CAT).

This paper reports the sequence of the cat gene and regulatory region carried by a $3.9 \mathrm{~kb} S$. intermedius

†Present address: Fa. Abbott GmbH, Diagnostika, Max PlanckRing 2, 6200 Wiesbaden Delkenheim, FRG.

The nucleotide sequence data reported in this paper have been submitted to GenBank and have been assigned the accession number M38702. plasmid. The relationship of this cat gene to those of the prototype $\mathrm{Cm}^{\mathrm{R}}$ plasmids $\mathrm{pC} 221$ and $\mathrm{pC} 194$ from $S$. aureus is also discussed.

\section{Methods}

Bacteria and growth conditions. A $S$. intermedius strain was isolated from a purulent skin infection of a dog and identified with the ATB 32 Staph-system (Bio Merieux). S. intermedius cultures were prepared by overnight incubation at $37^{\circ} \mathrm{C}$ on blood agar base (Gibco) supplemented with $7.5 \%(w / v)$ sheep blood. For plasmid isolation the bacteria were grown in brain heart infusion broth (Merck) overnight at $37^{\circ} \mathrm{C}$ on a rotary shaker at 175 r.p.m. $\mathrm{Cm}^{\mathrm{R}}$ of this $S$. intermedius strain was determined as previously described (Schwarz et al., 1989b).

Plasmid DNA isolation. A previously described modification of an alkaline lysis procedure was used (Schwarz \& Blobel, 1989) for smallscale plasmid preparation of the $S$. intermedius strain and the $S$. aureus pSCSI transformant. For large scale plasmid preparations the Qiagen system (Diagen) was modified. The modification involved disruption of the staphylococcal cell walls by incubation in P1-buffer supplemented with $40 \mu \mathrm{g} \mathrm{ml}^{-1}$ lysostaphin (Sigma) for $45 \mathrm{~min}$ at $37^{\circ} \mathrm{C}$.

Plasmid transformation. The $S$. intermedius plasmid was transferred into $S$. aureus RN4220 (Novick, 1967) by protoplast transformation (Schwarz et al., 1989a; Chang \& Cohen, 1979). Transformants were selected by incubation on DM3 regeneration plates (Chang \& Cohen, 1979), supplemented with $15 \mu \mathrm{g} \mathrm{Cm} \mathrm{ml} l^{-1}$, for $48-72 \mathrm{~h}$ at $37^{\circ} \mathrm{C}$.

Cloning experiments and sequence analyses. Restriction endonucleases were obtained from Boehringer and used according to the manufacturer's instructions. Standard DNA manipulation techniques were employed (Sambrook et al., 1989). pSCS1 DNA was cloned in pBluescript II $\mathrm{SK}^{+}$(Stratagene) using Escherichia coli XL-1 blue (Stratagene) as a host.

A $1.55 \mathrm{~kb}$ MboI fragment of pSCS1 was cloned in both orientations into the single BamHI site of the plasmid vector and a $0.9 \mathrm{~kb} T a q \mathrm{I}-$ $M b o I$ fragment was used for sequence analysis. DNA sequencing was 
performed by the dideoxy chain-termination method (Sanger $e t$ al., 1977) modified for double-stranded templates (Sambrook et al., 1989) using $T_{7}$ DNA polymerase (Tabor \& Richardson, 1987) and $\left[\alpha^{-35}\right.$ S]dATP $\left[>600 \mathrm{Ci} \mathrm{mmol}^{-1}\left(22 \mathrm{TBq} \mathrm{mmol}^{-1}\right)\right]$ from Amersham. DNA was sequenced on both strands using overlapping oligonucleotide primers. A first set of primers was purchased from Stratagene. From the sequence data obtained with these primers, four synthetic 17 mer oligonucleotide primers were designed, synthesized with an Applied Biosystems 380 B DNA synthesizer and used for sequence analyses (Brenner \& Shaw, 1985).

\section{Results and Discussion}

A Cm-resistant strain of $S$. intermedius was isolated from an infected dog. It harboured a single plasmid of $3.9 \mathrm{~kb}$ which carried the genetic determinant for $\mathrm{Cm}^{\mathrm{R}}$ as demonstrated by transformation into $S$. aureus. A restriction map of this plasmid, designated pSCS1, was constructed (Fig. 1) which allowed comparisons between pSCS1 and the three prototype $\mathrm{Cm}^{\mathrm{R}}$ plasmids $\mathrm{pC} 221$, pC223 and pC194 from $S$. aureus. Similarities between pC221 and pSCS1 were found in a $2 \mathrm{~kb}$ region which encodes, in pC221, CAT and a protein required for plasmid replication (REP). Subcloning showed that the cat gene was located within a $1.55 \mathrm{~kb} \mathrm{MboI} \mathrm{fragment.}$ This fragment was cloned in both orientations into pBluescript II SK ${ }^{+}$. Subsequently, E. coli XL-1 blue cells transformed with these recombinant plasmids were tested for $\mathrm{Cm}^{\mathrm{R}}$. In one orientation, E. coli $\mathrm{XL}-1$ blue demonstrated $\mathrm{Cm}^{\mathrm{R}}$ at $15 \mu \mathrm{g} \mathrm{Cm} \mathrm{m}{ }^{-1}$ while in the other orientation a higher level of $\mathrm{Cm}^{\mathrm{R}}$ occurred $(80 \mu \mathrm{g} \mathrm{Cm}$ $\mathrm{ml}^{-1}$ ).

As predicted from the restriction maps, DNA sequence analysis confirmed a high degree of similarity between the cat genes of pSCS1 and pC221. A901 bp TaqI-MboI fragment contained the complete cat structural gene and the regulatory region located about $80 \mathrm{bp}$ $5^{\prime}$ to the coding sequences. This region exhibited $97.9 \%$ identity with the corresponding region of $\mathrm{pC} 221$. Of the 19 variant bases, eight were within the cat gene coding region. Only five caused alterations in the amino acid sequence: Leu, Asn and Met in the pC221 CAT variant were replaced by the functionally similar residues Phe, Ser and Ile in CAT from pSCS1 (changes at positions 565,689 and 810 , respectively). The changes at positions 832 and 834 led to the replacement of His by Lys. Substitutions at positions 441,759 and 762 did not cause changes in the amino acid sequences. The active centre of CAT, His 196 (Leslie et al., 1988), was not affected. The other 11 alterations in the nucleotide sequence of pSCS1 were in non-coding regions (Fig. 2).

However, five base changes occurred in the regulatory region which comprises two Shine-Dalgarno (SD) sequences (SD1, positions 129-136 and SD2, positions 193-198), an open reading frame for a small peptide of

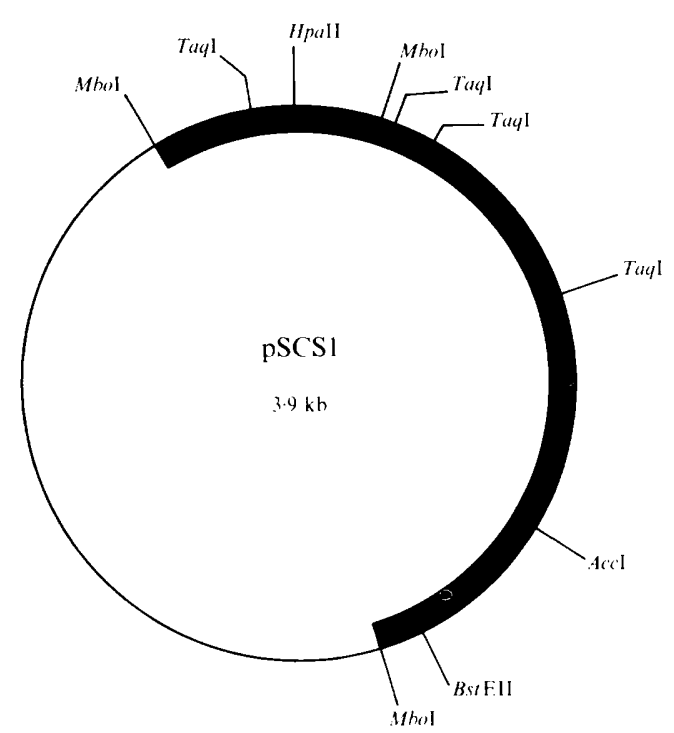

Fig. 1. Circular restriction map of the $\mathrm{Cm}^{\mathrm{R}}$ plasmid pSCS1 from $S$. intermedius. The black box indicates the region which showed extensive homologies to the REP/CAT region of the prototype plasmid $\mathrm{pC} 221$ from $S$ aureus.

nine amino acids (144-173) and inverted repeats at positions $163-175$ and 189-201. In mRNA the inverted repeats form a stem-loop structure (Brückner \& Matzura, 1985; Lovett, 1990) located immediately upstream from the CAT coding region (Fig. 3). This relatively, stable stem-loop is a transcription terminator and SD2 within the stem is not accessible to ribosomes (Lovett, 1990). In pC221, the relative stability of the stem-loop was $\Delta G=-18.0 \mathrm{kcal} \mathrm{mol}^{-1}\left(-75.3 \mathrm{~kJ} \mathrm{~mol}^{-1}\right.$; Tinoco et al., 1973). The base change from $\mathrm{A}$ in $\mathrm{pC} 221$ to $\mathrm{T}$ in pSCS1 at position 201 would lenghten the inverted repeat by $1 \mathrm{bp}$ and would increase the relative stability of the stem-loop to $-19.8 \mathrm{kcal} \mathrm{mol}^{-1}\left(-82.8 \mathrm{~kJ} \mathrm{~mol}^{-1}\right)$.

Moreover, two other important base substitutions occurred within SD1. This region of the mRNA interacts with its complement in the $16 \mathrm{~S}$ rRNA. This interaction is essential for the subsequent translation of the cat gene. Despite the stem-loop structure, ribosomes are presumably able to bind to SD1. Translation of the small open reading frame, which is highly conserved in all sequenced cat genes in the pC221 family (Brenner \& Shaw, 1985; Brückner \& Matzura, 1985), might be expected to destabilize the stem-loop structure (Brückner \& Matzura, 1985; Lovett, 1990), making SD2 accessible to ribosomes and allowing translation of the cat structural gene (Lovett, 1990). The exchanges from G in pC221 to A in pSCS1 at position 130, and from $\mathrm{C}$ in pC221 to $\mathrm{T}$ in pSCS1 at position 136, within SD1, would increase the free energy of the binding of mRNA to $16 \mathrm{~S}$ rRNA from $-11.4 \mathrm{kcal} \mathrm{mol}^{-1}\left(-47.7 \mathrm{~kJ} \mathrm{~mol}^{-1}\right)$ in the case of $\mathrm{pC} 221$, to $-17.8 \mathrm{kcal} \mathrm{mol}^{-1}\left(-74.5 \mathrm{~kJ} \mathrm{~mol}^{-1}\right)$ in the case of 
\begin{tabular}{l|lllll} 
& 10 & 30 & 40 & 50 & 60
\end{tabular}

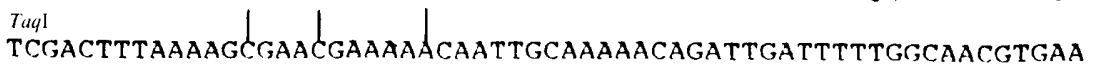
$\begin{array}{rrrrrr}70 & 80 & 90 & 100 & 110 & 120\end{array}$

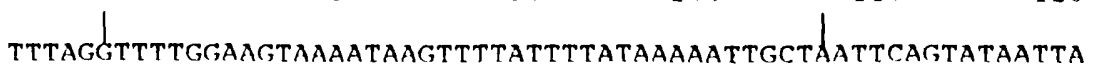

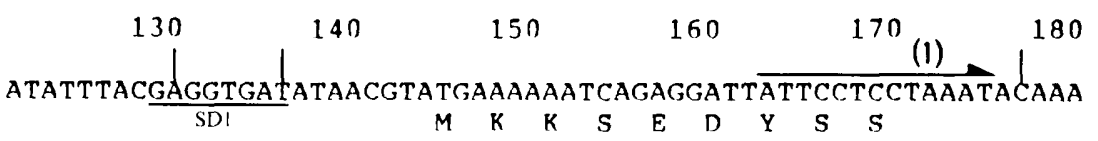

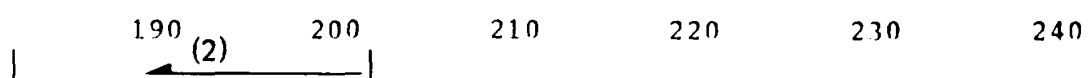

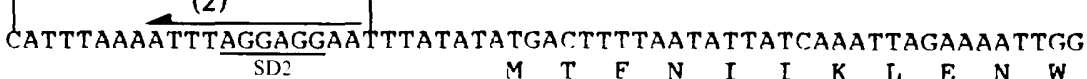
$\begin{array}{lllll}250 & 260 & 270 & 280 & 290\end{array}$

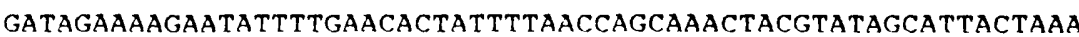
$\begin{array}{llllllllllllllllllll}D & R & K & E & Y & F & E & H & Y & E & N & Q & Q & T & T & Y & S & I & T & K\end{array}$ $\begin{array}{llllll}310 & 320 & 330 & 340 & 350 & 360\end{array}$ GAAATTGATATTACTTTGTTTAAAGATATGATAAAAAAGAAAgGatATGAAATTTATCCT $\begin{array}{llllllllllllllllllll}E & I & D & I & T & L & E & K & D & M & T & K & K & K & G & Y & E & I & Y & P\end{array}$ $\begin{array}{llllll}370 & 380 & 390 & 400 & 410 & 420\end{array}$

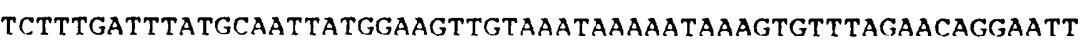
$\begin{array}{lllllllllllllllllllll}S & L & I & Y & A & I & M & E & V & V & N & K & N & K & V & F & R & T & G & I\end{array}$ $\begin{array}{llllll}430 & 440 & 450 & 460 & 470 & 480\end{array}$

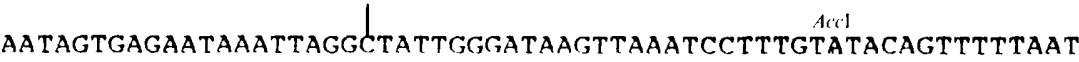
$\begin{array}{llllllllllllllllllll}N & S & E & N & K & L & G & Y & W & D & K & L & N & P & I & Y & T & V & F & N\end{array}$

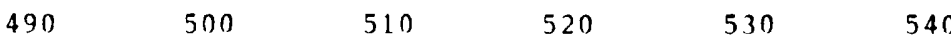
AAGCAAACTGAAAAATTACTAACATTTGgACTGAATCTGATAACAACTTCACTTCTTTT

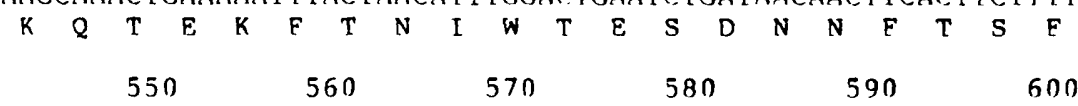

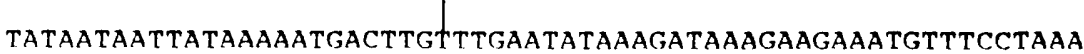
$\begin{array}{llllllllllllllllllll}Y & N & N & Y & K & N & D & L & E & E & Y & K & D & K & E & E & M & F & P & K\end{array}$ $\begin{array}{lllll}610 & 620 & 630 & 640 & 650\end{array} 660$ AAACCGATACCTGAAAACACCATACCGATTTCAATGATTCCTTGGatTGATTTTAGTTCA $\begin{array}{llllllllllllllllllll}K & P & I & P & E & N & T & I & P & I & S & M & I & P & W & I & D & F & S & S\end{array}$ $\begin{array}{rrrrr}670 & 680 & 690 & 700 & 710\end{array}$

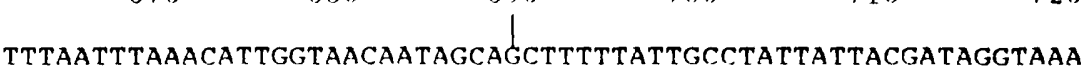
$\begin{array}{llllllllllllllllllll} & N & L & N & I & G & N & N & S & S & F & L & L & P & I & I & T & I & G & K\end{array}$ $\begin{array}{llllll}730 & 740 & 750 & 760 & 770 & 780\end{array}$

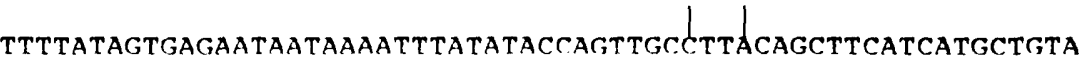
$\begin{array}{llllllllllllllllllll}\mathrm{E} & \mathrm{Y} & \mathrm{S} & \mathrm{E} & \mathrm{N} & \mathrm{N} & \mathrm{K} & \mathrm{I} & \mathrm{Y} & \mathrm{I} & \mathrm{P} & \mathrm{V} & \mathrm{A} & \mathrm{L} & \mathrm{Q} & \mathrm{L} & \mathrm{H} & \mathrm{H} & \mathrm{A} & \mathrm{V}\end{array}$ $\begin{array}{llllll}790 & 800 & 810 & 820 & 830 & 840\end{array}$

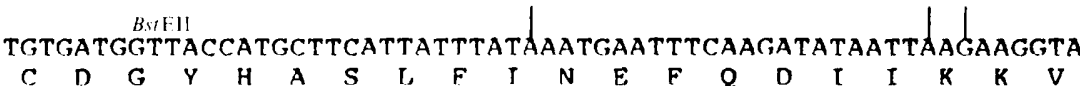
$\begin{array}{llllll}850 & 860 & 970 & 880 & 890 & 900\end{array}$

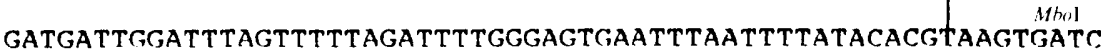
$D$ D $W$ I
Fig. 2. DNA sequence of the $0.9 \mathrm{~kb}$ TaqI-MboI fragment containing the cat structural gene and its regulatory region, presented as the non-coding strand. Two putative Shine-Dalgarno sequences (SD1, SD2) are marked. The arrows indicate the extent of the inverted repeats (1) and (2). Positions of basepair changes with respect to $\mathrm{pC} 221$ are marked by vertical lines. The amino acid sequences of the two open reading frames, deduced from the respective nucleotide sequences, are displayed in the singleletter code. 


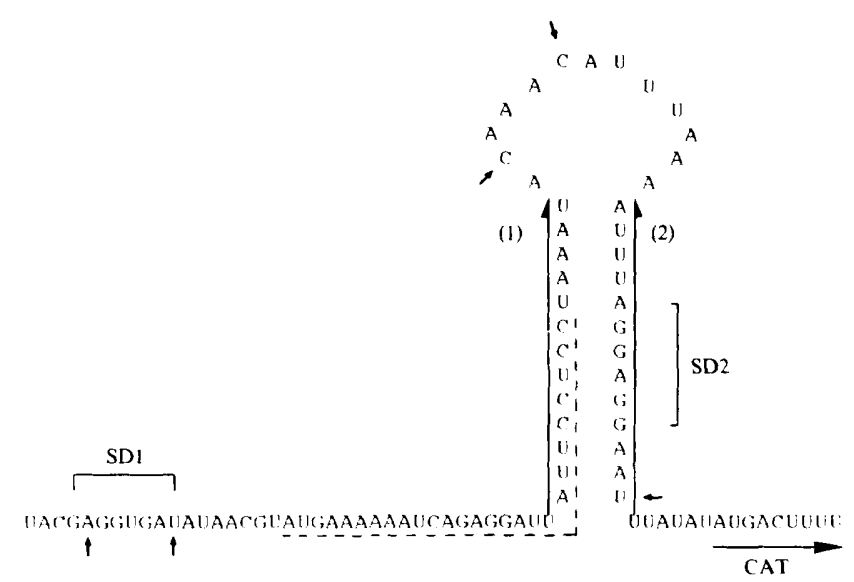

Fig. 3. Probable stem-loop configuration in mRNA transcribed from the cat gene control region. The two putative SD sequences (SD1, SD2) as well as the inverted repeats (1) and (2) are marked. The small arrows indicate the positions in which basepair differences occur with respect to $\mathrm{pC} 221$. The dotted line indicates the coding sequence for a nine amino acid peptide.

pSCS1. These two mutations probably result in a stronger translation initiation signal. However, the mutation at position 210 would result in a more stable RNA stem-loop, which might represent a stronger block for initiation of translation of the cat gene. Thus, the mutations seem to cause opposite effects, with a stronger translation initiation signal being required to destabilize a more stable RNA stem-loop structure. The remaining two basepair changes within the regulatory region, at positions 177 and 181 , should not cause any conformational or energetic changes.

Comparisons of the DNA sequence of the cat fragment of pSCS1 with the corresponding region of pC194 from $S$. aureus (Horinouchi \& Weisblum, 1982) revealed $62.9 \%$ identity, while the amino acid sequence of CAT from pSCSI shared only $53.5 \%$ identity with CAT from $\mathrm{pC} 194$.

On the basis of the similarities in the restriction map of the REP/CAT region of $\mathrm{pC} 221$ and $\mathrm{pSCS} 1$, the $S$. intermedius plasmid could be assigned to the pC221 family of staphylococcal $\mathrm{Cm}^{\mathrm{R}}$ plasmids. This was confirmed by comparisons of nucleotide sequences. The presence of similar REP/CAT regions in $\mathrm{Cm}^{\mathrm{R}}$ plasmids of the pC22I family isolated from different staphylococcal species in different geographical areas had been observed before (Gillespie \& Skurray, 1988; Schwarz et $a l ., 1989 a, b, 1990 a, b)$. The widespread occurrence of this highly conserved REP/CAT region might be a consequence of plasmid mobilization and subsequent interplasmid recombination. The presence of the mob genes and the mobilization site oriT in pC221 (Novick, 1989) might have allowed the mobilization of pC221 into other species by conjugative plasmids (Novick, 1989).
Site-specific interplasmid recombination might occur (Novick, 1989) with plasmids resident in the new hosts. Two sequences which flank the REP/CAT region, namely a recombination site $\mathrm{B}$ and the CAT terminator, were shown to be involved in such recombinational events and might also be responsible for spreading the REP/CAT region among other plasmids, thus extending the pC221 family of plasmids (Gillespie \& Skurray, 1988; Projan et al., 1985; Novick et al., 1984). In this way, new plasmids could be formed (Lampson \& Parisi, 1986) which are better adapted to the new bacterial host.

The authors wish to thank Mrs Sabine Grölz-Krug and Mrs Ute Neuschulz for their skilful technical assistance, Mr Rolf Ware for help in computer analysis, as well as Professor Dr G. Hobom and Professor Dr H. Blobel for helpful discussions.

\section{References}

Brenner, D. G. \& Shaw, W. V. (1985). The use of synthetic oligonucleotides with the universal templates for rapid DNA sequencing: results with staphylococcal replicon pC221. EMBO Journal 4, 561-568.

BRÜCKNER, R. \& MatzURA, H. (1985). Regulation of the inducible chloramphenicol acetyltransferase gene of Staphylococcus aureus plasmid pUB112. EMBO Journal 4, 2295-2300.

CHANG, S. \& COHEN, S. N. (1979). High frequency transformation of Bacillus subtilis protoplasts by plasmid DNA. Molecular and General Genetics 168, 111-115.

Gillespie, M. T. \& SkURRAY, R. A. (1988). Structural relationships among chloramphenicol-resistance plasmids of Staphylococcus aureus. FEMS Microbiology Letters 51, 205-210.

Horinouchi, S. \& Weisblum, B. (1982). Nucleotide sequence and functional map of $\mathrm{pC194}$, a plasmid that specifies inducible chloramphenicol resistance. Journal of Bacteriology 150, 815-825.

Lampson, B. C. \& Parisi, J. T. (1986). Nucleotide sequence of the constitutive macrolide-lincosamide-streptogramin B resistance plasmid pNE131 from Staphylococcus epidermidis and homologies with Staphylococcus aureus plasmids pE194 and pSN2. Journal of Bacteriology 167, 888-892.

LesLie, A. G. W., Moody, P. C. E. \& ShaW, W. V. (1988). Structure of chloramphenicol acetyltransferase at $1.75 \AA$ resolution. Proceedings of the National Academy of Sciences of the United States of America 85, 4133-4137.

LOVETT, P. S. (1990). Translational attenuation as the regulator of inducible cat genes. Journal of Bacteriology 172, 1-6.

LYON, B. R. \& SKURRaY, R. A. (1987). Antimicrobial resistance of Staphyloccus aureus: genetic basis. Microbiological Reviews 51, 88 134.

Novick, R. P. (1967). Properties of a cryptic high frequency transducing phage in Staphylococcus aureus. Virology 33, 155-166.

Novick, R. P. (1989). Staphylococcal plasmids and their replication. Annual Review of Microbiology 43, 537-565.

Novick, R. P., Projan, S. J., Rosenblum, W. \& Edelman, I. (1984). Staphylococcal plasmid cointegrates are formed by host-and phagemediated general rec systems that act on short regions of homology. Molecular and General Genetics 195, 374-377.

Projan, S. J., Kornblum, J., Moghazeh, S. L., Edelman, I., Gennaro, M. L. \& Novick, R. P. (1985). Comparative sequence and functional analysis of pT 181 and pC221, cognate plasmid replicons from Staphylococcus aureus. Molecular and General Genetics 199, 452-464.

Sambrook, J., Fritsch, E. F. \& Maniatis, T. (1989). Molecular Cloning : a Laboratory Manual, 2nd edn. Cold Spring Harbor, NY: Cold Spring Harbor Laboratory. 
Sanger, F., Nicklen, S. \& Coulsen, A. (1977). DNA sequencing with chain terminating inhibitors. Proceedings of the National Academy of Sciences of the United States of America 74, 5463-5467.

SCHWARZ, S. \& BlOBEL, H. (1989). Plasmids and resistance to antimicrobial agents and heavy metals in Staphylococcus hyicus from pigs and cattle. Journal of Veterinary Medicine 36, 669-673.

Schwarz, S., Cardoso, M. \& Blobel, H. (1989a). Plasmid-mediated chloramphenicol resistance in Staphylococcus hyicus. Journal of General Microbiology 135, 3329-3336.

Schwarz, S., Cardoso, M. \& Blobel, H. (1989b). Plasmid-encoded resistance to chloramphenicol in 'canine' Staphylococcus intermedius isolates. Medical Science Research 17, 451-453.

SChwarz, S., Cardoso, M. \& Blobel, H. (1990 a). Detection of a novel chloramphenicol resistance plasmid from 'equine' Staphylococcus sciuri. Journal of Veterinary Medicine 37, 674-679.

Schwarz, S., Cardoso, M., Grölz-Krug, S. \& Blobel, H. (1990b) Common antibiotic resistance plasmids in Staphylococcus aureus and
Staphylococcus epidermidis from human and canine infections. Zentralblatt für Bakteriologie 273, 369-377.

SHaw, W. V. (1984). Chloramphenicol acetyltransferase: enzymology and molecular biology. CRC Critical Reviews of Biochemistry 14, $1-46$.

TABOR, S. \& RICHARDSON, G. C. (1987). DNA sequence analysis with a modified bacteriophage T7 DNA polymerase. Proceedings of the National Academy of Sciences of the United States of America 84, 4767-4771.

Tinoco, I. JR, Borer, P. N., Dengler, B., Levine, M. D., Uhlenbeck, O. C., Crothers, D. M. \& Gralla, J. (1973). Improved estimation of secondary structure in ribonucleic acids. Nature New Biology 246, 40-41.

YUNIS, A. A. (1973). Chloramphenicol-induced bone marrow suppression. Seminars in Hematology. 10, 225. 